\title{
The Relationship Between Coronavirus Anxiety Level and Emotional Eating in Individuals with Metabolic Syndrome: A Comparative Study
}

\section{Duygu Mataracı Değirmenci}

Ordu University: Ordu Universitesi

Yasemin Kalkan Uğurlu ( $\square$ yasemin_kalkan24@hotmail.com )

Ordu University https://orcid.org/0000-0003-0096-5593

Dilek Küçük Alemdar

Ordu University

Original Article

Keywords: Anxiety, COVID-19, Eating, Metabolic Syndrome

Posted Date: February 2nd, 2021

DOI: https://doi.org/10.21203/rs.3.rs-161715/v1

License: (c) (i) This work is licensed under a Creative Commons Attribution 4.0 International License.

Read Full License 


\section{Abstract}

\section{Background}

The aim was to determine the coronavirus anxiety levels and emotional eating status of cases with diagnosis of MetS according to diagnostic criteria published by the International Diabetic Federation (IDF) in 2005 and healthy individuals with similar BMI to MetS subjects.

\section{Methods}

This study was completed with the descriptive, cross-sectional, case-controlled and relational screening model. The full sampling method was used in the study. The study was completed with 105 individuals with metabolic syndrome attending the diet clinic and 109 healthy individuals without MetS diagnosis also attending the diet clinic. Collection of data used anthropometric measurements and biochemical findings, blood pressure and a survey form, the Coronavirus Anxiety Scale (CAS) and Emotional Eating Scale (EES).

Results

Coronavirus anxiety scale scores of individuals with metabolic syndrome were found to be statistically significantly higher than the scores of the healthy control group $(p<0.05)$. The difference between the metabolic syndrome group and the healthy control group for emotional eating scale scores was not significant $(\mathrm{p}<0.05)$ When groups are compared, apart from $\mathrm{HDL}$, blood pressure and all other biochemical parameters were higher in metabolic syndrome subjects $(p<0.05)$. However, when the correlation between coronavirus anxiety scale and emotional eating scale points is investigated in metabolic syndrome and healthy individuals, there was no correlation between the two scales $(p>0.05)$.

\section{Conclusion}

Individuals with metabolic syndrome had higher coronavirus anxiety levels than healthy individuals; however, there was no difference between metabolic syndrome and healthy subjects in terms of emotional eating behavior.

Level of evidence

III, case-control analytic study.

\section{Introduction}

Metabolic syndrome (MetS) is a clinical tableau involving risk factors with strong correlation to diabetes mellitus and cardiovascular diseases. Some of these risk factors are hypertension, glucose intolerance, dyslipidemia and abdominal obesity. It is thought that psychosocial, genetic and environmental factors play roles in development of the syndrome, though the pathophysiological mechanisms causing the 
syndrome are still being researched [1, 2]. Studies about this topic reported a strong correlation between psychological factors like depression or anxiety with metabolic syndrome [3, 4]. Though epidemiological studies have researched the correlation between anxiety and MetS, results are inconsistent. Some authors state that MetS patients have more anxiety disorder, while there are authors that do not state this correlation. Meta-analysis results of Tang et al. including 18 cross-sectional studies revealed a correlation between anxiety and MetS [5].

The effect of negative feelings like anxiety on food intake is complicated and not fully understood. Negative emotions are stated to reduce food intake in some individuals, while in others they may increase food intake [6-8]. The situation called emotional eating (EE) directs individuals to consume more than their daily requirements and may increase weight gain and cause obesity [9]. Additionally, obesity studies have stated that emotional eating by people is associated with lower rates of weight loss [10].

The coronavirus disease 2019 (COVID-19) causing severe acute respiratory syndrome linked to the virus SARS-CoV-2 was first reported in China in December 2019 and was declared an international public health emergency situation by the World Health Organization (WHO) on 30 January 2020 [11]. COVID-19 rapidly increased in north America and Europe in March 2020 and was first reported in Turkey on 11 March 2020. Within 4 months after observation of the first case, the total number of people infected in Turkey reached 201,000 with deaths of more than 5000 [12]. According to contact levels of asymptomatic patients and expert predictions, the general death rate of COVID-19 is about 1.4-2.3\%, with more severe progression of disease and higher death rates in a variety of risk groups. These risk groups include patients with cardiovascular disease, hypertension, chronic respiratory tract diseases, diabetes mellitus (DM) and metabolic syndrome [13-15]. People have a tendency to experience fear and anxiety during infectious disease epidemics, with COVID-19 causing generalized anxiety among individuals in risk groups like those with metabolic syndrome due to high infection and mortality rates $[16,17]$.

In short, the announcement of the new viral pneumonia emerging in Wuhan city in China in December 2019 by WHO, the rapid spread of the virus all around the world and the high mortality rates in individuals with metabolic syndrome has caused generalized anxiety in the whole society and especially among individuals with metabolic syndrome $[5,18]$. For this reason, the aim was to perform a comparative study to measure the coronavirus anxiety levels during the pandemic among individuals with metabolic syndrome and the correlation with emotional eating status.

\section{Materials And Methods}

\section{Procedure}

This study was completed with a descriptive, cross-sectional, case-controlled and relational screening model. The aim was to determine the correlation between coronavirus anxiety levels and emotional eating status of subjects with MetS diagnosis according to criteria published by the International Diabetes Federation (IDF) in 2005 and healthy individuals with similar BMI to MetS cases. All subjects attended a diet clinic in an education-research hospital in the north of Turkey. 
In addition to - abdominal obesity (waist circumference $\geq 94 \mathrm{~cm}$ in men, $\geq 80 \mathrm{~cm}$ in women, individuals should abide by at least two of the following criteria

1. High fasting blood glucose $(\geq 100 \mathrm{mg} / \mathrm{dL}$ ) or presence of type 2 diabetes

2. High triglyceride levels (>150 mg/dL)

3. Low HDL level ( $<40 \mathrm{mg} / \mathrm{dL}$ in men, $<50 \mathrm{mg} / \mathrm{dL}$ in women)

4. High blood pressure $(\geq 130 / 85 \mathrm{mmHg})$

\section{Selection Criteria}

The case group for the research included individuals aged over 18 years of age, with metabolic syndrome diagnosis according to IDF-2005 diagnostic criteria, who were not pregnant or breastfeeding, without any psychological disorder diagnosed by psychiatry, without diagnosis of COVID-19 and not using any psychiatric medications.

The healthy control group in the research included healthy individuals aged 18 years and older, who were not pregnant or breastfeeding, without any psychological disorder diagnosed by psychiatry, not using any psychiatric medications, without diagnosis of COVID-19, without any chronic disorder, and with similar BMI to the individuals in the subject group.

\section{Sample size}

The full sampling method was used in the study. Between 20 June 2020 following relaxation of limitations linked to the pandemic in Turkey and before social isolation rules began to be implemented again due to increasing case numbers on 20 November 2020, the study included 105 individuals with metabolic syndrome attending the diet clinic and 109 healthy individuals attending the diet clinic but without MetS diagnosis.

\section{Outcome Measures}

A survey form was applied to metabolic syndrome and healthy individuals included in the study face-toface. This survey questioned demographic data, anthropometric measurements (body weight, height, waist circumference, hip circumference) and biochemical findings (glucose, HDL, LDL, total cholesterol, triglycerides, CRP, HbA1c, insulin, HOMA-IR). Blood pressure was measured and recorded. The coronavirus anxiety scale (CAS) and emotional eating scale (EES) were applied.

\section{Demographic Characteristics:}

The age, sex, occupation and marital status of individuals was questioned. 
The body weight and body composition of participants were measured in bare feet, with thin clothing and no metal accessories on the body using the bioelectrical impedence analysis (BIA) method with a TANITA BC 418 device. When performing measurements, care was taken that individuals had not performed any intense physical activity for 24 hours before measurements, had not used alcohol, had not eaten 2-4 hours before the test and had not drunk water before the test.

The height of participants was measured without shoes, with feet together and head in Frankfort plane with the aid of a meter stick fixed to a wall. Waist circumference measurements were taken by finding the center point between the lowest rib and the crista iliaca and measuring with an inflexible measuring tape. Hip circumference measurements were taken at the highest point of hip circumference while standing beside the participant with the aid of an inflexible measuring tape [19]. BMI calculation divided the body weight in $\mathrm{kg}$ by the square of the height in meters [20].

\section{Biochemical Results:}

Some biochemical findings of participants were recorded from the patient files (glucose, HDL, LDL, total cholesterol, triglyceride, CRP, HbA1c, insulin, HOMA-IR, AST and ALT).

\section{Systolic and Diastolic Blood Pressure:}

Systolic and diastolic blood pressure was measured by a researcher trained in the topic using an Erka brand sphygmomanometer. Patients had not smoked, drunk tea or coffee, or eaten food or caffeine within 30 minutes before measurements and were questioned about whether antihypertensives were used. After a 3-5 minute rest period, measurements were recorded while patients were in sitting position at cardiac level in the arm.

\section{Coronavirus Anxiety Scale (CAS):}

The Coronavirus Anxiety Scale is a Likert-type scale. The scale comprises 5 questions and has a single dimension. Each item is rated from 0 (not at all) to 4 (nearly always) based on experiences during the pandemic. Total points of $\geq 9$ on the scale shows dysfunctional anxiety related to coronavirus. High points for a certain item or high total scale points $(\geq 9)$ show the individual has problematic symptoms that may require more advanced assessment and/or treatment. Clinical decisions guide interpretation of the scale results [21].

\section{Emotional Eating Scale (EES):}

The emotional eating scale comprises 10 items and three subdimensions. Questions are answered with 4 choices (never, sometimes, generally and all the time) on a Likert-type scale. The scale does not contain inverse items. Minimum " 0 " points and maximum " 30 " points can be obtained from the scale. High points on the scale show high levels of emotional eating behavior [22].

\section{Ethical Considerations}


In order to perform the study, institutional permission was granted by Ordu Provincial Directorate of Health and ethics committee permission was obtained from Ordu University Clinical Research Ethics Committee (2020/228). Each individual accepting participation in the study and abiding by the study criteria was given general information about the research and then provided signed consent stating they accepted participation in the study using the "Informed Consent Form For Studies For Research Purposes".

\section{Data Analysis}

SPSS 21.0 software was used for the data analysis. For the data, normal distribution was evaluated using the Shapiro-Wilk test. Frequency, percentage, arithmetic mean, standard deviation, minimum value, maximum value, $t$ test, chi-square, and Pearson correlation analysis were used for the evaluation of data. For the assessment of correlations between quantitative variables and for the determination of the type and power of the correlations between CAS and EES, Pearson correlation analysis was performed. The significance limit was chosen as $0.95(p<0.05)$.

\section{Findings}

The distributions of sex, occupation, marital status, changes in body weight during the pandemic and age of participants are shown in Table 1. Of individuals with metabolic syndrome, $76.2 \%$ were female, $81 \%$ were married, mean age was $44.08 \pm 11.71$ years and $49.5 \%$ were housewives. During the pandemic, the body weight of $53.3 \%$ of participants with metabolic syndrome had increased by mean $3.28 \pm 1.64 \mathrm{~kg}$, with $9.5 \%$ having mean $4.0 \pm 3.23 \mathrm{~kg}$ reduction in body weight. For healthy individuals, $80.7 \%$ were female, $78 \%$ were married, mean age was $40.86 \pm 10.70$ years and $36.7 \%$ were housewives. During the pandemic, $39.4 \%$ of healthy individuals did not experience any change in body weight, while $38.5 \%$ lost mean $4.66 \pm 3.00 \mathrm{~kg}$. The groups were identified to be similar in terms of sex, marital status, gained and lost weight amounts ( $p>0.05)$. However, there were statistically significant differences between the groups in terms of occupation, variations in body weight during the pandemic and age $(p<0.05)$.

The mean points for coronavirus anxiety scale and emotional eating scale in the groups are shown in Table 2. When coronavirus anxiety scale points are compared, individuals with metabolic syndrome had coronavirus anxiety scale points of $2.68 \pm 3.40$, while the healthy control group had points of $1.69 \pm 2.44$ and the difference between the groups was statistically significant $(p<0.05)$. For the emotional eating scale, points were $13.56 \pm 4.41$ for the metabolic syndrome group while they were $13.61 \pm 4.63$ in the healthy control group and the difference between the groups was not identified to be significant $(p>0.05)$.

The data related to blood pressure measurements and some biochemical findings like glucose, HDL, LDL, total cholesterol, triglyceride, $\mathrm{CRP}, \mathrm{HbA1c}$, insulin and insulin resistance of participants are shown in Table 3. Comparisons between the groups identified that, apart from HDS, blood pressure and all biochemical parameters were higher in individuals with metabolic syndrome $(p<0.05)$. HDL was identified to be higher in the healthy control group $(p<0.05)$. 
The data related to anthropometric measurements for the metabolic syndrome and healthy control groups are shown in Table 4. There were no differences between the groups in terms of BMI, waist circumference, hip circumference, waist/hip ratio and waist/height ratio $(p>0.05)$.

Table 5 investigates the correlation between coronavirus anxiety scale and emotional eating scale points for metabolic syndrome and healthy individuals. There was no significant correlation identified between the two scales $(p>0.05)$.

\section{Discussion}

There is no study assessing the anxiety levels of individuals with metabolic syndrome during the COVID19 pandemic; however, there are several studies investigating the correlation between MetS with mental health disorders like anxiety and depression [23-27]. The results of studies about this topic are contradictory. Skilton et al. identified that MetS was associated with depression and depressive symptoms but not with anxiety in a study investigating the correlation between anxiety, depression and metabolic syndrome [24]. A study researching the correlation between MetS with depression and anxiety in Japanese males reported that MetS was significantly correlated with MetS; however, there was no correlation with anxiety [25]. A cohort study dealing with the association between MetS with anxiety and depressive symptoms in a young adult population stated that there was no association between MetS with depression and anxiety [26]. Hildrum et al. reported there was no correlation between depression and anxiety with MetS in a study with 9571 participants from 20-89 years [27]. A study with 4256 participants by Carroll et al. found a close association between MetS with anxiety [23]. In our study, similar results to the study by Carroll et al. [23] were found, with total points on the coronavirus anxiety scale being high for metabolic syndrome individuals by a significant level compared to individuals in the healthy control group $(\mathrm{p}<0.05)$ (Table 2$)$.

There was no study encountered assessing the emotional eating status of metabolic syndrome patients during the pandemic; however, there are studies related to emotional eating behavior in other populations during this period [28-30]. A study of pregnant women during the pandemic showed that the COVID-19 pandemic triggered emotional eating behavior in pregnant women [28]. A study with 995 participants in India investigated the effect of COVID-19 on behavior related to lifestyle and observed that while healthy meal consumption increased during the pandemic, consumption of unhealthy foods reduced [30]. A study evaluating the association between eating behavior and metabolic syndrome identified a positive association between emotional eating and metabolic syndrome in women [31]. One of the components of metabolic syndrome of insulin resistance/diabetes affects appetite mechanisms and emotional eating behavior may emerge. Pearson et al. [32] investigated the correlations of fasting blood sugar levels and insulin resistance with depression and nutritional habits in a study of 1732 participants from 26-36 years of age. The results of the study found the presence of insulin resistance was correlated with depression and indirectly with emotional eating behavior. Another study with similar results assessed the association between depression and emotional eating behavior in type 2 diabetes and reported that there was a significant association between depression status and emotional eating behavior in type 2 diabetes [33]. 
In this study, emotional eating points of participants were assessed by noting the presence of metabolic syndrome (Table 2). As a result, there was no significant difference between emotional eating points between the metabolic syndrome and health control groups ( $p>0.05)$. The COVID-19 pandemic is a public health problem affecting all sections of society. All people faced with this problem and experiencing quarantine were psychologically affected and this situation is thought to encourage emotional eating behavior of all individuals without regard to health and disease status.

It is expected that the blood pressure, glucose and values related to lipid metabolism will be outside the reference interval for individuals with metabolic syndrome [34-36]. In this study, the mean fasting blood glucose of individuals was $110.82 \pm 12.14 \mathrm{mg} / \mathrm{dL}$ for participants with metabolic syndrome and this finding was above the marker for disrupted fasting glucose of $100 \mathrm{mg} / \mathrm{dL}$ according to the IDF 2005 criteria. This finding shows that the fasting blood glucose of the healthy control group was within the reference values (Table 3). As expected, there was a statistically significant difference identified between the fasting blood glucose values of both groups $(p<0.05)$ (Table 3$)$.

Glycosylated hemoglobin ( $\mathrm{HbA} 1 \mathrm{c})$ is an important and reliable parameter to monitor blood sugar and is expected to be below $5.7 \%$ in healthy individuals. The $\mathrm{HbA} 1 \mathrm{c}$ value being from $5.7-6.5 \%$ is prediabetes, while values above $6.5 \%$ are diagnostic criteria for diabetes [37]. In this study, the $\mathrm{HbA} 1 \mathrm{c}$ values for metabolic syndrome individuals were above the reference interval and the HbA1c in the healthy control group were within the desired reference interval and the difference between the groups was statistically significant $(\mathrm{p}<0.05)$ (Table 3$)$. Similar studies found the HbA1c value for individuals with metabolic syndrome were high [38-40]. In this study, the findings about for $\mathrm{HbA} 1 \mathrm{c}$ were similar to the literature.

HOMO-IR is a parameter used as marker of insulin resistance and values above 2.7 are seen as insulin resistance [41]. In this study, individuals with metabolic syndrome had HOMO-IR values of $6.13 \pm 3.71$ above the reference interval, as expected, and higher than the individuals in the healthy control group $(p<0.05)$ (Table 3). The HOMO-IR values in the healthy control group were above the reference interval which may be due to these individuals being chosen to have equal BMI to the individuals with metabolic syndrome.

High blood pressure is one of the diagnostic criteria for metabolic syndrome. Studies show that blood pressure measurements of individuals with metabolic syndrome are higher than for healthy individuals [42-44]. In this study, similar to the literature, the blood pressure of metabolic syndrome individuals was higher than the healthy control group and the difference between the groups was identified to be significant in statistical terms $(p<0.05)($ Table 3$)$.

A study by Erem et al. observed the LDL, total cholesterol and triglyceride levels of individuals with metabolic syndrome were above the reference interval [44]. Another study obtained similar results [4345]. In this study, only the triglyceride values in the metabolic syndrome group were higher than the reference interval; however, the HDL level was lower and LDL, total cholesterol and triglyceride levels were identified to be higher when compared with the healthy control group $(p<0.05)($ Table 3$)$. The obtained 
findings display the effect of disruptions in the lipid profile on the emergence of metabolic syndrome one more time.

One of the basic IDF 2005 diagnostic criteria for metabolic syndrome is abdominal obesity. For this reason, it is expected that the anthropometric measurements of individuals with metabolic syndrome will be above the reference interval. When creating the sample in the study, care was taken that participants in both groups had equal BMI. As a result, when the anthropometric measurements are compared in the groups, there was no statistically significant difference identified between anthropometric measurements of participants with metabolic syndrome and in the healthy control group ( $p>0.05$ ) (Table 4$)$. The similar features in terms of anthropometric measurements and lack of confusing factors in the groups ensure more pronounced display of the coronavirus anxiety and emotional eating status in metabolic syndrome individuals, which is the aim of our research.

A study by Alexander et al. investigated the correlation between emotional eating and anxiety in a study and found a positive significant correlation between them [46]. Similarly, a study by Nolan et al. identified that anxiety was effective on emotional eating [47]. A study by Carlos et al. reported an association between anxiety and emotional eating behavior [48]. In the literature, general anxiety status is the marker in studies related to anxiety and emotional eating behavior. There is no study assessing coronavirus anxiety and investigating the correlation with emotional eating behavior. This study investigated the association between coronavirus anxiety and emotional eating behavior for the first time, and contrary to expectations, there was no association found between coronavirus anxiety and emotional eating $(p>0.05)$ (Table 5).

\section{Conclusions}

The results of this study determined individuals with metabolic syndrome had higher coronavirus anxiety levels compared to healthy individuals; however, there was no difference between metabolic syndrome and healthy individuals in terms of emotional eating behavior. In conclusion, there was no correlation between coronavirus anxiety level and emotional eating behavior.

The increase in anxiety levels of individuals with metabolic syndrome during the coronavirus pandemic deeply affecting the whole world is an unwanted situation negatively affecting health. Reductions in anxiety may be ensured by giving psychological support to individuals with metabolic syndrome. There is a need for advanced studies investigating the correlation between coronavirus anxiety levels and emotional eating behavior in specific patient groups like metabolic syndrome.

\section{Limitations of the Study}

A limitation of the research is that only individuals attending the diet clinic in one hospital were included. For this reason, the results obtained in the research are limited to this sample and cannot be generalized to the whole society. 


\section{Declarations}

\section{Financial support}

There was no financial support for this study.

\section{Conflict of Interest}

There is no conflict of interest in this study.

\section{Acknowledgements}

We are grateful to the dietitians working in the diet clinic and study participants.

\section{References}

1. Elder SJ, Lichtenstein AH, Pittas AG, Roberts SB, Fuss PJ, Greenberg AS, et al (2009) Genetic and environmental influences on factors associated with cardiovascular disease and the metabolic syndrome. J Lipid Res 50(9):1917-26 doi: 10.1194/jlr.P900033-JLR200

2. Stančáková A, Laakso M (2014) Genetics of metabolic syndrome. Rev Endocr Metab Disord 15(4):243-52 doi: 10.1007/s11154-014-9293-9

3. Baxter A, Scott K, Vos T, Whiteford H (2013) Global prevalence of anxiety disorders: a systematic review and meta-regression. Psychol Med 43(5):897 doi: 10.1017/S003329171200147X

4. Kessler RC, Aguilar-Gaxiola S, Alonso J, Chatterji S, Lee S, Ormel J, et al (2009) The global burden of mental disorders: an update from the WHO World Mental Health (WMH) surveys. Epidemiol Psichiatr Soc 18(1):23 doi: 10.1017/s1121189x00001421

5. Tang F, Wang G, Lian Y (2017) Association between anxiety and metabolic syndrome: A systematic review and meta-analysis of epidemiological studies. Psychoneuroendocrinology 77:112-21 doi: 10.1016/j.psyneuen.2016.11.025

6. Heatherton TF, Herman CP, Polivy J (1991) Effects of physical threat and ego threat on eating behavior. J Pers Soc Psychol 60(1):138 doi: 10.1037//0022-3514.60.1.138

7. Baucom DH, Aiken PA (1981) Effect of depressed mood on eating among obese and nonobese dieting and nondieting persons. J Pers Soc Psychol 41(3):577 doi: 10.1037//0022-3514.41.3.577

8. Schneider KL, Appelhans BM, Whited MC, Oleski J, Pagoto SL (2010) Trait anxiety, but not trait anger, predisposes obese individuals to emotional eating. Appetite 55(3):701-6. doi:

10.1016/j.appet.2010.10.006

9. Hays NP, Roberts SB (2008) Aspects of eating behaviors "disinhibition" and "restraint" are related to weight gain and BMI in women. Obesity 16(1):52-8 doi: 10.1038/oby.2007.12

10. Elfhag K, Rössner S (2005) Who succeeds in maintaining weight loss? A conceptual review of factors associated with weight loss maintenance and weight regain. Obes Rev 6(1):67-85 doi: 10.1111/j.1467-789X.2005.00170.x 
11. Lee SA (2020) Coronavirus Anxiety Scale: A brief mental health screener for COVID-19 related anxiety. Death Stud 44(7):393-401 doi: 10.1080/07481187.2020.1748481

12. T.C. Sağlık Bakanlığı COViD-19 Bilgilendirme Sayfası https://covid19.saglik.gov.tr/ Accessed 25 December 2020

13. Zhou F, Yu T, Du R, Fan G, Liu Y, Liu Z, et al (2020) Clinical course and risk factors for mortality of adult inpatients with COVID-19 in Wuhan, China: a retrospective cohort study. Lancet 395(10229):1054-1062. doi: 10.1016/S0140-6736(20)30566-3

14. Fang L, Karakiulakis G, Roth M (2020) Are patients with hypertension and diabetes mellitus at increased risk for COVID-19 infection? Lancet Respir Med 8(4):e21. doi: 10.1016/S22132600(20)30116-8

15. Gupta R, Ghosh A, Singh AK, Misra A (2020) Clinical considerations for patients with diabetes in times of COVID-19 epidemic. Diabetes Metab Syndr 14(3):211. doi: 10.1016/j.dsx.2020.03.002

16. Ahorsu DK, Lin C-Y, Imani V, Saffari M, Griffiths MD, Pakpour AH (2020) The fear of COVID-19 scale: development and initial validation. Int J Ment Health Addict 27:1-9. doi: 10.1007/s11469-020-002708.

17. Lin C-Y (2020) Social reaction toward the 2019 novel coronavirus (COVID-19). Soc Health Behav 3(1):1. doi: 10.4103/SHB.SHB_11_20

18. Lee SA, Mathis AA, Jobe MC, Pappalardo EA (2020) Clinically significant fear and anxiety of COVID19: A psychometric examination of the Coronavirus Anxiety Scale. Psychiatry Res 290:113112. doi: 10.1016/j.psychres.2020.113112.

19. Baysal A, Aksoy M, Besler T, Bozkurt N, Keçecioğlu S, Mercanlıgil S et al (2013) Diyet El Kitabı. ANKARA: Hatiboğlu Yayınları 67-142

20. Organization WH. Global Database on Body Mass Index (BMI) Classification 2020 [Available from: http://www.euro.who.int/en/health-topics/disease-prevention/nutrition/a-healthy-lifestyle/bodymass-index-bmi

21. Evren C, Evren B, Dalbudak E, Topcu M, Kutlu N (2020) Measuring anxiety related to COVID-19: A Turkish validation study of the Coronavirus Anxiety Scale. Death Stud https://doi.org/10.1080/07481187.2020.1774969

22. Arslantaş H, Dereboy F, Yüksel R, İnalkaç S (2019) Duygusal yeme ölçeği'nin türkçe çevirisinin geçerlik ve güvenirlik çalışması. Türk Psikiyatri Dergisi. 2019;30. doi: 10.5080/u23520.

23. Carroll D, Phillips AC, Thomas GN, Gale CR, Deary I, Batty GD (2009) Generalized anxiety disorder is associated with metabolic syndrome in the Vietnam experience study. Biol Psychiatry 66(1):91-3. doi: 10.1016/j.biopsych.2009.02.020.

24. Skilton MR, Moulin P, Terra J-L, Bonnet F (2007) Associations between anxiety, depression, and the metabolic syndrome. Biol Psychiatry 62(11):1251-7. doi: 10.1016/j.biopsych.2007.01.012.

25. Takeuchi T, Nakao M, Nomura K, Yano E (2009) Association of metabolic syndrome with depression and anxiety in Japanese men. Diabetes Metab Res Rev 35(1):32-6. doi: 10.1002/dmrr.1041. 
26. Herva A, Räsänen P, Miettunen J, Timonen M, Läksy K, Veijola J, et al (2006) Co-occurrence of metabolic syndrome with depression and anxiety in young adults: the Northern Finland 1966 Birth Cohort Study. Psychosom Med 68(2):213-6. doi: 10.1097/01.psy.0000203172.02305.ea.

27. Hildrum B, Mykletun A, Midthjell K, Ismail K, Dahl A (2009) No association of depression and anxiety with the metabolic syndrome: the Norwegian HUNT study. Acta Psychiatr Scand 120(1):14-22. doi: 10.1111/j.1600-0447.2008.01315.x.

28. Zhang J, Zhang Y, Huo S, Ma Y, Ke Y, Wang P, et al (2020) Emotional eating in pregnant women during the COVID-19 pandemic and its association with dietary intake and gestational weight gain. Nutrients 12(8):2250. doi: 10.3390/nu12082250.

29. Kalkan Uğurlu Y, Mataracı Değirmenci D, Durgun H, Gök Uğur H (2020) The examination of the relationship between nursing students' depression, anxiety and stress levels and restrictive, emotional, and external eating behaviors in COVID-19 social isolation process. Perspectives in Psychiatric Care https://doi.org/10.1111/ppc.12703

30. Chopra S, Ranjan P, Singh V, Kumar S, Arora M, Hasan MS, et al (2020) Impact of COVID-19 on lifestyle-related behaviours-a cross-sectional audit of responses from nine hundred and ninety-five participants from India. Diabetes Metab Syndr 14(6):2021-30. doi: doi: 10.1016/j.dsx.2020.09.034.

31. Song Y-M, Lee K (2019) Eating behavior and metabolic syndrome over time. Eat Weight Disord 25(3):545-552. doi: 10.1007/s40519-019-00640-9.

32. Pearson S, Schmidt M, Patton G, Dwyer T, Blizzard L, Otahal P, et al (2010) Depression and insulin resistance: cross-sectional associations in young adults. Diabetes care 33(5):1128-33. doi: 10.2337/dc09-1940.

33. González-Cantú A, Mireles-Zavala L, Rodríguez-Romo A, Olavide-Aguilar E, De la Garza-Hernández NE, Romero-lbarguengoitia ME (2018) Eating behaviors and emotional distress are predicted by treatment and adverse outcome in patients with type 2 diabetes. Psychol Health Med 23(3):325-36. https://doi.org/10.1080/13548506.2017.1363897.

34. Annani-Akollor ME, Laing EF, Osei H, Mensah E, Owiredu E-W, Afranie BO, et al (2019) Prevalence of metabolic syndrome and the comparison of fasting plasma glucose and $\mathrm{HbA} 1 \mathrm{c}$ as the glycemic criterion for MetS definition in non-diabetic population in Ghana. Diabetol metab Syndr 11(1):26. https://doi.org/10.1186/s13098-019-0423-0.

35. Mayans L (2015) Metabolic syndrome: insulin resistance and prediabetes. FP Essent 435:11-6. PMID: 26280343.

36. Martínez-Larrad MT, Corbatón-Anchuelo A, Fernández-Pérez C, Lazcano-Redondo Y, Escobar-Jiménez F, Serrano-Ríos M (2016) Metabolic syndrome, glucose tolerance categories and the cardiovascular risk in Spanish population. Diabetes Res Clin Pract 114:23-31. doi: 10.1016/j.diabres.2016.02.003.

37. Chamberlain JJ, Rhinehart AS, Shaefer Jr CF, Neuman A (2016) Diagnosis and management of diabetes: synopsis of the 2016 American Diabetes Association Standards of Medical Care in Diabetes. Ann Intern Med 164(8):542-52. https://doi.org/10.7326/M15-3016. 
38. Siu PM, Yuen QS (2014) Supplementary use of HbA1c as hyperglycemic criterion to detect metabolic syndrome. Diabetol Metab Syndr 6(1):119. doi: 10.1186/1758-5996-6-119.

39. Sun X, Du T, Huo R, Yu X, Xu L (2013) Impact of HbA1c criterion on the definition of glycemic component of the metabolic syndrome: the China health and nutrition survey 2009. BMC Public Health 13(1):1045. doi: 10.1186/1471-2458-13-1045.

40. Succurro E, Marini MA, Arturi F, Grembiale A, Fiorentino TV, Andreozzi F, et al (2011) Usefulness of hemoglobin A1c as a criterion to define the metabolic syndrome in a cohort of italian nondiabetic white subjects. Am J Cardiol 107(11):1650-5. https://doi.org/10.1016/j.amjcard.2011.01.055.

41. Fan Z, Cao B, Long H, Feng L, Li Q, Zhang Y et al (2019) Independent association of vitamin $D$ and insulin resistance in obstructive sleep apnea. Ann Endocrinol (Paris) 80(5-6):319-323. https://doi.org/10.1016/j.ando.2019.09.004.

42. Jouyandeh Z, Nayebzadeh F, Qorbani M, Asadi M (2013) Metabolic syndrome and menopause. J Diabetes Metab Disord 12(1):1. doi: 10.1186/2251-6581-12-1.

43. Gundogan K, Bayram F, Gedik V, Kaya A, Karaman A, Demir O et al (2013) Metabolic syndrome prevalence according to ATP III and IDF criteria and related factors in Turkish adults. Arch Med Sci 9(2):243-53. doi: 10.5114/aoms.2013.34560.

44. Erem C, Hacıhasanoglu A, Deger O, Topbaş M, Hosver I, Ersoz HO et al (2008) Prevalence of metabolic syndrome and associated risk factors among Turkish adults: Trabzon MetS study. Endocrine 33(1):9-20. doi: 10.1007/s12020-008-9044-3.

45. Silva VM, Vinagre CG, Dallan LA, Chacra AP, Maranhão RC (2014) Plasma lipids, lipoprotein metabolism and HDL lipid transfers are equally altered in metabolic syndrome and in type 2 diabetes. Lipids 49(7):677-84. doi: 10.1007/s11745-014-3899-2.

46. Alexander KE, Siegel HI (2013) Perceived hunger mediates the relationship between attachment anxiety and emotional eating. Eat Behav 14(3):374-7. doi: 10.1016/j.eatbeh.2013.02.005.

47. Nolan LJ, Jenkins SM (2019) Food Addiction Is Associated with Irrational Beliefs via Trait Anxiety and Emotional Eating. Nutrients 11(8):1711. doi: 10.3390/nu11081711.

48. Carlos M, Elena B, Teresa IM (2020) Are Adherence to the Mediterranean Diet, Emotional Eating, Alcohol Intake, and Anxiety Related in University Students in Spain? Nutrients 12(8):2224. doi: $10.3390 /$ nu12082224.

\section{Tables}

Table 1. Demographic Characteristics of Participants 


\begin{tabular}{|c|c|c|c|c|c|c|}
\hline & \multicolumn{2}{|c|}{$\begin{array}{l}\text { With Metabolic } \\
\text { Syndrome }(n=105)\end{array}$} & \multicolumn{2}{|c|}{$\begin{array}{l}\text { Healthy } \\
\text { Control } \\
(n=109)\end{array}$} & \multirow[b]{2}{*}{$x^{2} / t$} & \multirow[b]{2}{*}{$\mathbf{p}$} \\
\hline & $\mathrm{n}$ & $\%$ & $\mathbf{n}$ & $\%$ & & \\
\hline \multicolumn{7}{|l|}{ Sex } \\
\hline Female & 80 & 76.2 & 88 & 80.7 & \multirow[t]{2}{*}{$0.654^{b}$} & \multirow[t]{2}{*}{0.419} \\
\hline Male & 25 & 23.8 & 21 & 19.3 & & \\
\hline \multicolumn{7}{|l|}{ Job } \\
\hline Officer & 13 & 12.4 & 33 & 30.3 & \multirow[t]{6}{*}{$17.865^{b}$} & \multirow[t]{6}{*}{$0.003^{* *}$} \\
\hline Housewife & 52 & 49.5 & 40 & 36.7 & & \\
\hline Worker & 9 & 8.6 & 19 & 17.4 & & \\
\hline Student & 11 & 10.5 & 6 & 5.5 & & \\
\hline Self-employment & 15 & 14.3 & 8 & 7.3 & & \\
\hline Retired & 5 & 4.8 & 3 & 2.8 & & \\
\hline \multicolumn{7}{|l|}{ Marital Status } \\
\hline Married & 85 & 81.0 & 85 & 78.0 & \multirow[t]{3}{*}{$0.306^{b}$} & \multirow[t]{3}{*}{0.858} \\
\hline Single & 19 & 18.0 & 23 & 21.1 & & \\
\hline Widowed & 1 & 1.0 & 1 & 0.9 & & \\
\hline \multicolumn{7}{|c|}{$\begin{array}{l}\text { Has there been any change in your } \\
\text { weight during the pandemic? }\end{array}$} \\
\hline No & 39 & 37.1 & 43 & 39.4 & \multirow[t]{3}{*}{$7.888^{b}$} & \multirow[t]{3}{*}{$0.019 *$} \\
\hline Yes, I gained weight & 56 & 53.3 & 42 & 38.5 & & \\
\hline Yes, I lost weight & 10 & 9.5 & 24 & 22.0 & & \\
\hline \multicolumn{7}{|c|}{$\begin{array}{l}\text { Weight change in individuals who } \\
\text { gain weight }\end{array}$} \\
\hline Mean \pm SD & \multicolumn{2}{|c|}{$3.28 \pm 1.64$} & \multicolumn{2}{|c|}{$3.84 \pm 2.04$} & $-1.518^{a}$ & 0.132 \\
\hline Med (Min-Max) & \multicolumn{2}{|c|}{$3.0(1.0-9.0)$} & \multicolumn{2}{|c|}{$3.5(1.0-10.0)$} & & \\
\hline \multicolumn{7}{|c|}{$\begin{array}{l}\text { Weight change in individuals who } \\
\text { lose weight }\end{array}$} \\
\hline Mean $\pm S D$ & \multicolumn{2}{|c|}{$4.0 \pm 3.23$} & \multicolumn{2}{|c|}{$4.66 \pm 3.00$} & $-0.670^{a}$ & 0.508 \\
\hline Med (Min-Max) & \multicolumn{2}{|c|}{$3.0(1.0-12.0)$} & \multicolumn{2}{|c|}{$4.0(1.0-13.0)$} & & \\
\hline
\end{tabular}




\begin{tabular}{|c|c|c|c|c|}
\hline Mean $\pm S D$ & $44.08 \pm 11.71$ & $40.86 \pm 10.70$ & $2.102^{a}$ & $0.037 *$ \\
\hline Med (Min-Max) & $46.0(20.0-64.0)$ & $\begin{array}{l}40.0(21.0- \\
64.0)\end{array}$ & & \\
\hline
\end{tabular}

${ }^{*} \mathrm{p}<0.05,{ }^{* *} \mathrm{p}<0.01,{ }^{\mathrm{a}}$ Independent Sample t Test and ${ }^{\mathrm{b}}$ Pearson Chi-square test were used for numerical data and categorical data, respectively

Table 2. Coronavirus Anxiety Scale and Emotional Eating Scale Scores of Participants

\begin{tabular}{|c|c|c|c|c|}
\hline & $\begin{array}{l}\text { With Metabolic Syndrome } \\
(n=105)\end{array}$ & $\begin{array}{l}\text { Healthy Control } \\
(n=109)\end{array}$ & $\mathrm{t}$ & $p$ \\
\hline & Mean $\pm S D$ & Mean $\pm S D$ & & \\
\hline & Med (Min-Max) & Med (Min-Max) & & \\
\hline \multirow{2}{*}{$\begin{array}{l}\text { Coronavirus Anxiety Scale } \\
\text { Total Score }\end{array}$} & $2.68 \pm 3.40$ & $1.69 \pm 2.44$ & 2.470 & $0.014^{*}$ \\
\hline & $2.0(0.0-17.0)$ & $0(0-9)$ & & \\
\hline \multirow{2}{*}{$\begin{array}{l}\text { Emotional Eating Scale Total } \\
\text { Score }\end{array}$} & $13.56 \pm 4.41$ & $13.61 \pm 4.63$ & -0.070 & 0.944 \\
\hline & $14.0(3.0-25.0)$ & $14(3-23)$ & & \\
\hline
\end{tabular}

${ }^{*} \mathrm{p}<0.05$, Independent Sample t Test was used for scale scores

Table 3. Blood Pressure and Biochemical Findings of Participants 


\begin{tabular}{|c|c|c|c|c|c|}
\hline & $\begin{array}{l}\text { Reference } \\
\text { Range }\end{array}$ & $\begin{array}{l}\text { With Metabolic } \\
\text { Syndrome }(n=105)\end{array}$ & $\begin{array}{l}\text { Healthy Control } \\
(n=109)\end{array}$ & $t$ & $\mathrm{p}$ \\
\hline & & Mean士SD & Mean士SD & & \\
\hline & & Med (Min-Max) & Med (Min-Max) & & \\
\hline \multirow{2}{*}{$\begin{array}{l}\text { Systolic Blood } \\
\text { Pressure }\end{array}$} & \multirow[t]{2}{*}{-} & $130.57 \pm 11.32$ & $123.67 \pm 9.61$ & \multirow[t]{2}{*}{4.800} & \multirow[t]{2}{*}{$0.000 * \star *$} \\
\hline & & $130(105-160)$ & $120(100-150)$ & & \\
\hline \multirow{2}{*}{$\begin{array}{l}\text { Diastolic Blood } \\
\text { Pressure }\end{array}$} & \multirow[t]{2}{*}{-} & $91.14 \pm 13.59$ & $83.72 \pm 9.89$ & \multirow[t]{2}{*}{4.556} & \multirow[t]{2}{*}{$0.000 * \star *$} \\
\hline & & $90(65-120)$ & $80(60-120)$ & & \\
\hline \multirow[t]{2}{*}{ Glucose (mg/dL) } & \multirow[t]{2}{*}{ 70-100 } & $110.82 \pm 12.14$ & $90.35 \pm 5.59$ & \multirow[t]{2}{*}{15.749} & \multirow[t]{2}{*}{$0.000 * \star *$} \\
\hline & & $107(90-153)$ & $90(78-99)$ & & \\
\hline \multirow[t]{2}{*}{$\mathrm{HDL}(\mathrm{mg} / \mathrm{dL})$} & \multirow[t]{2}{*}{-} & $46.39 \pm 9.38$ & $52.25 \pm 10.96$ & \multirow[t]{2}{*}{-4.194} & \multirow[t]{2}{*}{$0.000 * * *$} \\
\hline & & $45(24-76)$ & $51(31-78)$ & & \\
\hline \multirow[t]{2}{*}{ LDL (mg/dL) } & \multirow[t]{2}{*}{$<130$} & $118.38 \pm 34.64$ & $105.09 \pm 26.84$ & \multirow[t]{2}{*}{3.128} & \multirow[t]{2}{*}{$0.002 * *$} \\
\hline & & $111.8(51-248)$ & $\begin{array}{l}104.8(39.4- \\
202.2)\end{array}$ & & \\
\hline \multirow{2}{*}{$\begin{array}{l}\text { Total Cholesterol } \\
\text { (mg/dL) }\end{array}$} & \multirow[t]{2}{*}{$<200$} & $195.16 \pm 43.03$ & $179.34 \pm 33.31$ & \multirow[t]{2}{*}{2.994} & \multirow[t]{2}{*}{$0.003^{* *}$} \\
\hline & & $198(100-324)$ & $\begin{array}{l}179.5(109- \\
300)\end{array}$ & & \\
\hline \multirow{2}{*}{$\begin{array}{l}\text { Triglyceride } \\
(\mathrm{mg} / \mathrm{dL})\end{array}$} & \multirow[t]{2}{*}{$<150$} & $171.49 \pm 105.89$ & $121.95 \pm 52.59$ & \multirow[t]{2}{*}{4.309} & \multirow[t]{2}{*}{$0.000 * \star *$} \\
\hline & & $155(60-913)$ & $113(43-316)$ & & \\
\hline \multirow[t]{2}{*}{ CRP (mg/dL) } & \multirow[t]{2}{*}{$<0.5$} & $0.55 \pm 0.48$ & $0.4 \pm 0.39$ & \multirow[t]{2}{*}{2.439} & \multirow[t]{2}{*}{$0.016 *$} \\
\hline & & $0.35(0.06-1.8)$ & $\begin{array}{l}0.27(0.04- \\
2.81)\end{array}$ & & \\
\hline \multirow[t]{2}{*}{ HbA1c (\%) } & \multirow[t]{2}{*}{$4-5.7$} & $5.95 \pm 0.65$ & $5.43 \pm 0.53$ & 4.629 & $0.000 * * *$ \\
\hline & & $5.8(4.9-8.5)$ & $5.5(2.27-5.9)$ & & \\
\hline Insulin (ng/ml) & $2.6-24.9$ & $22.06 \pm 12.26$ & $15.03 \pm 8.6$ & 4.657 & $0.000 * * *$ \\
\hline & & $19.99(5.3-66.95)$ & $\begin{array}{l}12.32(4.42- \\
50.75)\end{array}$ & & \\
\hline Homa-IR (index) & $0-2.5$ & $6.13 \pm 3.71$ & $3.40 \pm 2.02$ & 6.483 & $0.000 * * *$ \\
\hline & & $5.24(1.36-23.17)$ & $\begin{array}{l}2.82(0.93- \\
12.28)\end{array}$ & & \\
\hline
\end{tabular}

${ }^{*} p<0.05,{ }^{*} p<0.01,{ }^{* \star} p<0.001$, Independent Sample t Test was used for biochemical findings 
Table 4. Anthropometric Measurements of the Participants

\begin{tabular}{|c|c|c|c|c|c|}
\hline & & $\begin{array}{l}\text { With Metabolic Syndrome } \\
(n=105)\end{array}$ & $\begin{array}{l}\text { Healthy Control } \\
(n=109)\end{array}$ & $\mathbf{t}$ & $\mathbf{p}$ \\
\hline & \multirow{2}{*}{$\begin{array}{l}\text { Reference } \\
\text { Range }\end{array}$} & Mean $\pm S D$ & Mean $\pm S D$ & & \\
\hline & & Med (Min-Max) & Med (Min-Max) & & \\
\hline \multirow[t]{2}{*}{ BMI } & \multirow[t]{2}{*}{$18.5-24.9$} & $34.29 \pm 6.16$ & $33.25 \pm 5.63$ & 1.292 & 0.198 \\
\hline & & $33.65(0.92-52.09)$ & $\begin{array}{l}32.38(25.13- \\
51.23)\end{array}$ & & \\
\hline \multirow{2}{*}{$\begin{array}{l}\text { Waist } \\
\text { Circumference }\end{array}$} & $\begin{array}{l}\leq 80 \\
\text { (female) }\end{array}$ & $105.45 \pm 11.53$ & $102.49 \pm 11.07$ & 1.916 & 0.057 \\
\hline & $\leq 94$ (male) & $103(88-140)$ & 102. (73 - 129) & & \\
\hline \multirow{2}{*}{$\begin{array}{l}\text { Hip } \\
\text { Circumference }\end{array}$} & \multirow[t]{2}{*}{-} & $113.79 \pm 9.68$ & $112.6 \pm 8.41$ & 0.769 & 0.336 \\
\hline & & $114(91-147)$ & $113(92-134)$ & & \\
\hline \multirow[t]{3}{*}{ Waist/Hip Ratio } & \multirow{2}{*}{$\begin{array}{l}\leq 0.85 \\
\text { (female) }\end{array}$} & $0.93 \pm 0.12$ & $0.91 \pm 0.1$ & 0.148 & 0.229 \\
\hline & & $0.89(0.75-1.24)$ & $0.89(0.72-1.2)$ & & \\
\hline & $\begin{array}{l}\leq 0.90 \\
\text { (male) }\end{array}$ & & & & \\
\hline \multirow{2}{*}{$\begin{array}{l}\text { Waist/Height } \\
\text { Ratio }\end{array}$} & \multirow[t]{2}{*}{$<0.5$} & $0.64 \pm 0.08$ & $0.63 \pm 0.07$ & 0.881 & 0.379 \\
\hline & & $0.63(0.12-0.89)$ & $0.63(0.45-0.87)$ & & \\
\hline
\end{tabular}

${ }^{*} \mathrm{p}<0.05$, Independent Sample t Test was used for anthropometric measurement

Table 5. The Relationship Between the Coronavirus Anxiety Scale and Emotional Eating Scale Scores of Participants

\begin{tabular}{|c|c|c|c|}
\hline & & \multicolumn{2}{|c|}{ Total Emotional Eating Scale Score } \\
\hline & & $\begin{array}{l}\text { With Metabolic } \\
\text { Syndrome } \\
\qquad(n=105)\end{array}$ & $\begin{array}{l}\text { Healthy Control } \\
(n=109)\end{array}$ \\
\hline \multirow[t]{2}{*}{$\begin{array}{l}\text { Total Coronavirus Anxiety Scale } \\
\text { Score }\end{array}$} & $r$ & $-0,007$ & 0,067 \\
\hline & $p$ & 0,946 & 0,490 \\
\hline
\end{tabular}

${ }^{*} \mathrm{p}<0.05, r$ : Pearson Correlation Analysis 